\title{
DIE SAAMTREK VAN CALVINISTE TE POTCHEFSTROOM.
}

As indrukke oor so 'n saak soos bgn. Saamtrek weergegee moet word, dan dring die volgende op jou aan: wat is indrukke iets erg-persoonliks! Daarom kan wat hier volg nie aangedien word as iets algemeens nie, maar wel as iets persoonliks. En tog word die hoop gekoester dat ander met ondergetekende kan saamstem ....

Reeds vroeg in die jaar het o.a. ek ook al gevra: kan daar nie 'n kort sendingkursus of iets dergeliks gereëi word, sodat in wyer kringe geprofiteer kan word van die besoek van prof. Bavinck nie? En werklik, dit was maantlik om ' $n$,iets dergeliks" te kry: die Calvinistiese Saamtrek op 28 Sept.-1 Okt.

Die Teologiese Senaat-wat saam met die reëlingskomitee hiervoor dank verdien-het geen sendingkursus gereël nie, omdat dit miskien in beperkte kringe belangstelling sou geniet. Hulle reël egter 'n groot saam- 
trek van Calviniste, toeganklik vir almal wat hulleself graag Calviniste noem. Dit sou dus nie 'n saamtrek van Gereformeerde lidmate wees nic, maar van alle Calviniste in ons land.

'n Eerste indruk was dat diegene wat gevolg gegee het aan die uitnodiging en opgedaag het, werklik een van hart en een van sin is. Dit het by 'n mens ' $n$ gevoel van bykans ontroering gewek om te belewe: van orals af is ons saam en hoort ons saam! Dit was geen kerklike vergadering nie, maar 'n byeenkoms wat sig op wyer terrein bevind. Daarom was hierdie samehorigheidsgevoel inderdaad verkwikkend. En so sou dit seker nog in ruimer sin gewees het, as daar ook „ander" Calviniste was.

'n Sekere mate van teleurstelling kan seker nie misken word nie. So in byeenkoms is tog iets waarna ons kan verlang. Daarom dat die bywoning aanvanklik werklik ietwat teleurstellend was. En tog-dit sou ek wil neerskryf as ' $n$ volgende indruk-tog was die geesdrif reg! Aanvanklik was daar miskien 'n kleine honderdtal mense. Maar dit het nie verhinder dat daar sommiges was wat saans na Johannesburg is om die volgende more weer te kom nie. Dit skep tog duidelik die indruk dat daar bereidheid was om op te offer om teenwoordig te wees. En dit is bemoedigend.

deur ds. W. VENTER.

Al skryf dr. Kempff dan in Die Kerkblad: „Ons vat so min vlam vir 'n saak soos hierdie. Maar 'n toetswedstryd?"- - dan vind ons tog in die gretigheid om daar te kon wees-al was dit miskien maar by 'n klein getal die geval -'n voorbeeld van 'n teenbeeld van die dolle humanisme.

Aanvanklik klein, het die bywoning algaande beter geword. Diegene wat eers later daar aangekom het, het rede tot spyt, want seker nie een wat daar was, sal daar ooit spyt van hê nie. Dit kon inteendeel alleenlik oorsaak van dankbare vreugde wees!

\section{Waarom dan?}

Omdat wat daar gebied is verrykend was. Omdat dit 'n voorreg was om soveel goeds te ontvang. In 'n mooie verskeidenheid is daar van die beste gegee. Veral as ons bedink dat die tyd seer beperk was, en ons beskou dan nogmaals die program, dan kom ons seker onder die indruk: wat' $n$ keurige verskeidenheid van geestesverrykende geleenthede.

Want neem maar die heel eerste nommer op die program: die bveen 
koms in die Gimnasiumsaal. Die samesyn daar en die toesprake gelewer, het net een indruk geskep: die gelowige se weg is skoon! Wie sal nie onthou watter gewaarwordinge hom deurwoel het toe prof. Snyman so onderhoudend mededelings gedoen het oor sy besoek aan Montpellier en Edinburgh nie-ryke lewenskrag wat gebied word deur byeenkomste soos in die twee plekke, en dit net omdat so duidelik die getuienis gehoor en (veral in Frankryk i.v.m. die Hugenote) gesien kan word dat die waarheid van God bly! Voorts ook 'n skone weg vir die gelowige soos geblyk het uit die getuienis wat een en andermaal van prof. Bavinck verneem is, dat die Here hom wonderlik gelei het om hom feitelik midde uit smartlike beproewing te neem en na Suid-Afrika te bring om 'n tydlank hier te werk. Sulke getuienisse bevestig tog onmiskenbaar dat die Here sy woord gestand doen: Kyk, Ek is met julle .... Die Here is sy volk immer trou naby!

Die hoofskotel was die lesings van prof. Bavinck. En die indruk wat hierdeur nagelaat is, is skoon. Temeer nog as bedink word dat dit gcen w'etenskaplike kursus was nie, maar 'n woord van hart tot hart. In 'n tweetal lesings het prof. Bavinck ons sterk onder die indruk gebring van die grootte en grootsheid van die saak ter tafel: die wêreld verkeer in diepe nood, en al wat die nood kan verlig, is om die mens in Christus te kry, want as iemand in Christus is, dan is hy ' $n$ nuwe skepsel. Die geagte professor het gewis die indruk nagelaat: „In der Beschränkung zeigt sich der Meister". Want die doel is seker bereik, nl. dat 'n verhoogde bewustheid van ons verantwoordelikheid t.o.v. die sending gekweek is. As ons nou maar net nie weer indut en verflou nie! Want die saak is wel so dringend, dat slaperigheid hier ten ergste misplaas is.

Dit is egter nie al indruk wat opgedoen is by die hoor en bespreking van die twee lesings nie. ' $n$ Ander ewe belangrike is seker die volgende: die Here het ons 'n groot genade bewys dat juis op ons, Calviniste, die verantwoordelikheid geplaas is om instrumente in sy hande te wees om die nood van die wêreld te verlig. Dit nie op die modern-humanistiese of liberalistiese of kommunistiese manier nie, maar op Calvinistiese: om medewerkers van God te wees. So is die lewe en die taak van die Calvinis Godverankerd--die lewe van elke gelowige wat as Christen ook deel het aan die salwing van Christus en derhalwe staan in die profetiese, priesterlike en koninklike ampte. 'n Groot, maar tewens ook verrykende verantwoordelikheid. En gewis het ons onder die indruk gekom van 'n magtige taak: die hand moet aan die ploeg geslaan word en daar gehou word. 
Prof. Bavinck het ook 'n predikantekonferensie saam met ander belangstellendes toegespreek oor: De Preek. Weereens: 'n Bavinckiaanse aflewering-deeglik, gloedvol, liefderyk, pakkend. Die groot taak van die prediker is ten duidelikste beklemtoon: dit gaan om die Woord van God en die verkondiging daarvan. Die prediker verkeer in direkte kontak met God deur te verneem en aan sy Woord te ontworstel: wat wil God aan die gemeente sê? Hierdie boodskap moet dan op verantwoorde wyse deurgegee word. Wat ' $n$ indruk maak dit nie op 'n mens nie! Dit is of mens saam met Moses sy „Ag Here ....” wil uitsug, om dan te verneem: „Ek sal met jou mond .... wees en julle leer ....". Geen wonder nie dat ds. H. J. Venter (Nylstroom) na hierdie lesing gesê het dat die skets wat die teenwoordiges ter hand gestel is, lank by hom op sy lessenaar gaan wees!

In 'n afskeidsrede het die besoekende professor sy indrukke oor ons land kortliks meegedeel. En wat' $n$ taak het ek nou! Om 'n indruk van 'n indruk te gee! Tog sou ek hieroor samevattend wou sê: my indruk was en is dit, dat die mededeling van die indruk van prof. Bavinck ons tot die ernstigste nadenke moet bring! Ons woon in 'n land met 'n ontsaglike toekoms. Wat sal die toekoms word? En juis hier die geweldigheid van die indruk, dat in die lig van Gods Woord hier 'n worstelstryd geworstel sal moet word-'n stryd en 'n toekoms waarin nie gevra mag word wat mense wil nie, maar die volle oorgegewendheid van: wat wil $U$ ?

Dit was met gemengde gevoelens dat ons hierdie man, klein van postuur, maar groot in genade, sien gaan het. Hy het in die paar dae vir ons 'n rykdom van nadenkingstof gegee. Daarom dat dit moeilik was om iemand met wie jy jou so een mag voel, te sien vertrek na verre geweste, maar aan die anderkant ook weer iets vreugdevols om te mog geniet en te weet dat deur Gods genade ' $n$ dienskneg van Hom in 'n kort spanne tyds -insonderheid nog gedurende die paar dae van die Saamtrek-in staat gestel is om aan Calvinistiese Suid-Afrika iets besonders te bied. Ek noem dit met volle oortuiging ,iets besonders", omdat dit nie klatergoud was nie, maar fonkelgoud uit die juiste bron: Gods Woord.

Benewens bgn., was daar nog die eerste kongres van die A.C.B. Uit die aard van die saak was daar nog nie 'n groot agenda om verwerk te word nie. Tog is ook hier belangrike werk verrig. Miskien nog ietwat soekende, maar tog met 'n doelgerigtheid: daar moet aangepak word. Want die saak waarom dit gaan, is om in die sig steeds sterker opdringende antitese die juiste staanplek te vind. En dan nie 'n staanplek om op te bly staan nie, maar om vandaar'n suiwere aksie te loods, om suiwer te beweeg-daarom 'n Beweging. 
Vir hierdie kongres was die belangsteliing miskien ook ietwat teleurstellend. Te veel het nog die indruk geskep van „waarnemers" te wees. En ons kan nie langer non-aktiewe waarnemers bly nie. Ook hier is 'n stryd wat begin is wat gestry moet word tot ons sterf of oorwin het. Alles gloei en woel; alles roep tot suiwere aksie. Daarom dat dit geen fariseïstiese bede is nie, as gesê word dat die bede is dat 'n vloedgolf van ontwaking deur ons Afrikaanse Calviniste sal heenstu om gereed te wees tot die stryd, om egte Calviniste te wees. En as „egte" kwalifiserend daarby kom, dan behoef dit geen verdere betoog meer dat tot die daad oorgegaan sal word nie, want die egte Calvinis is kragdadig en daadkragtig.

Daarom: KOMAAN!

Die verslag i.s. die P.U. vir C.H.O. en die bespreking van hierdie sake, het al vroeg op die agenda gestaan. Wat sou mens as indruk in hierdie verband wou neerskryf? Groot is die taak, maar hoe groot die kragte? Hierby kon die indruk nie anders wees nie as dat by almal wat hierdie inrigting vir C.H.O. liefhet, bereidheid moet wees om tot die uiterste toe te mobiliseer ter bevoordeling van die P.U. Vertrou op God en hou die kruit droog! Alleen kan ons nie-sonder God is daar vir ons ook hier geen toekoms nie. Maar ook kan en mag ons nie dadeloos wees nie. Hier is werk, verantwoordelike werk om gedoen te word, terwille van ons universiteit, ons volk, maar bo alles ter ere Gods.

Oor die herdenkingsfunksie i.v.m. die verskyning van die hersiene Afrikaanse Bybel . . . ja, wat sal ons hiervan sê? Sal woorde nie dalk vertroebelend wees nie? Sal dit nie die indruk weergee, as ons net herinner daaraan dat ons daar mog sing Ps. 119: 33, 39 nie? Ook hierdie gewyde oomblikke het ons toegekom uit die hand van God, dit was van ewigheid af so deur Hom besluit gewees-ook dit dat ons ons geliefde Totius hierby sou moes mis . . . - en die raad van die Here kan nie gekeer word nie; dit sal bestaan in ewigheid!

Sou dit verkeerd wees om te sê dat die indruk wat die Saamtrek in sy geheel nagelaat het-op wyer terrein dan-, verklank word in die beryming van Totius.

„Ek geloof aan die gemeenskap,

heilige verbintenis

van wie almal saam 'n eenheid

in hul Heer één liggaam is".?

Want ons het daar saam gevoel, saam geniet, saam besef dat die taak magtig groot is, maar ook saam onder die indruk gekom: „Die meetsnoere het vir my in lieflike plekke geval, ja my erfenis is vir my mooi”. 